\title{
Comparative proteomic analysis of drought and high temperature response in roots of two potato cultivars
}

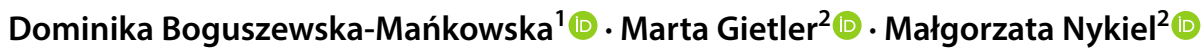

Received: 20 November 2019 / Accepted: 11 July 2020 / Published online: 16 July 2020

(c) The Author(s) 2020

\begin{abstract}
A comparative analysis of drought and high temperature responsive proteins, which means to provide insight into the molecular mechanism of potato stress tolerance. In the presented study, two potato cultivars, differing in dehydration tolerance, were compared. An analysis of their morphological, physiological and root proteome related traits proved that, although water shortage, as well as high temperatures cause the dehydration of plants, the response to those stresses at the proteome level was significantly different. LC-MS/MS protein identification showed that in roots of the sensitive cultivar, in response to drought, most changes concern increased abundance of defence- and detoxification-related proteins, while in tolerant plants, significant changes in abundance of energy and carbohydrate metabolism related proteins were observed (data are available via ProteomeXchange with identifier PXD020259). Moreover, in response to high temperatures, in the sensitive cultivar, decreased abundance of proteins involved in cell energetic metabolism was detected, while in the tolerant cultivar, the majority of proteins from this group was abundant. It can be suggested that such comparative proteome analysis indicates the fine tuning metabolism as a major factor of stress tolerance of potato plants.
\end{abstract}

Keywords Potato $\cdot$ Drought $\cdot$ High temperature $\cdot$ Root proteomics

\section{Introduction}

The ongoing climate change associated with increased temperature and reduced rainfall negatively impacts plant growth, development and crop yield (Chaves et al. 2003). The potato (Solanum tuberosum L.) is considered to be a crop species sensitive to drought (Monneveux et al. 2013) and high temperatures (Levy and Veilleux 2007). Even with moderate levels of soil moisture deficit, yield reductions are observed as a result of a decreased number, size and quality

Electronic supplementary material The online version of this article (https://doi.org/10.1007/s10725-020-00643-y) contains supplementary material, which is available to authorized users.

Małgorzata Nykiel

malgorzata_nykiel@sggw.edu.pl

1 Potato Agronomy Department, Plant Breeding and Acclimatization Institute - National Research Institute, 05-140 Jadwisin, Poland

2 Department of Biochemistry and Microbiology, Institute of Biology, Warsaw University of Life Sciences-SGGW , Building 37, Nowoursynowska St. 159, 02-776 Warsaw, Poland of the tubers. Additionally, the decrease in vegetative plant growth (leaves, stems, shoots and roots) and development (Aksoy et al. 2015; Dahal et al. 2019) plays a role in yield drop, as well. High temperatures delay tuber initiation and bulking, causing quality disorders such as malformation and necrosis of the tubers (Levy and Veilleux 2007).

The global production of potato is estimated at 377 million tonnes, on an area of about 19 million hectares (FAOSTAT 2016). However, water shortages can cause a potato yield reduction of up to $79 \%$ (Binod et al. 2015). Due to the climate changes, it is estimated that potential potato yield will decrease by 18 to $32 \%$ worldwide between 2040 and 2069 (Hijmans 2003). Rain shortage in 2010 in Russia led to approximately $30 \%$ yield losses on industrial potato farms (GAIN 2010), which caused significant financial losses. Similar situation is observed in various regions. Mittler (2006) studies showed that the losses in US agricultural production caused by drought amounted up to approximately USD 20 trillion in the years 1980-2004, and combined with the occurrence of high temperatures they reached USD 120 trillion. It often occurs that stress caused by heat and drought critically affects potato production (Ahn et al. 2004). 
Morphological and physiological characteristics of roots are closely correlated with plant drought resistance (Iwama 2008; Joshi et al. 2016; Zarzyńska et al. 2017). The potato has a rather shallow root system, which causes its high dependence on the regularity of rainfall and its sensitivity to periodic shortages of water (Joshi et al. 2016). Due to the scarcity of water and nutrients supplementation, as well as a disturbance in transport of chemical signals from root to shoot, plants suffering from water deficits are usually smaller, devoid of turgor, with a lighter colouring, and more sensitive to diseases and pest attacks (Chaves et al. 2003). Drought-tolerant potato cultivars developed elongated roots, whereas the roots of drought-sensitive cultivars remained at the same length (Zarzyńska et al. 2017; Boguszewska-Mańkowska et al. 2020). High temperature $\left(30^{\circ} \mathrm{C}\right)$ reduced the size of the root system in both heat-tolerant and heat-sensitive potato clones (Sattelmacher et al. 1990). Nevertheless, significant genotypic differences in the responses of potato plant roots to high temperature have been found (Minhas et al. 2001; Rykaczewska 2013).

The consequences of soil drought and high temperatures are osmotic and oxidative stresses in plants. Our previous experiments showed that increased activity of peroxidase, superoxide dismutase and catalase counteracted the accumulation of ROS (reactive oxygen species) in dehydrated leaves and tubers and in effect protected the plants against the loss of tuber yield (Boguszewska et al. 2010). Despite the fact that both investigated cultivars (Gwiazda and Oberon) have a common parental cultivar (Denar), they differed in drought tolerance and avoidance mechanisms (BoguszewskaMańkowska et al. 2018; Pieczyński et al. 2018). Droughtavoidant potato plants experienced lower water deficits due to specific morpho-physiological traits such as greater root length (Chaves et al. 2003).

To identify the strategies used by potato plants to cope with consequences of soil drought and high temperature, high-throughput techniques have been developed that allow for the understanding of the mechanisms involved in the regulation of desirable traits. Our previous experiments on transcriptosome differences between two selected pairs of potato cultivars (Gwiazda/Oberon and Tajfun/Owacja) that are closely related to each other but differ in the drought tolerance, allowed for the identification of genes responsive to drought (Pieczyński et al. 2018). The selected genes exhibited evolutionary conservation in their function in the plant's response to water shortage. Therefore, a proteomic analysis of two potato cultivars, drought-tolerant (Gwiazda) and drought-sensitive (Oberon), was performed to determine proteins differentially abundant in response to drought and high temperature. Such approach is required to confirm the hypothesis that there are differences in the response to stress between resistant and sensitive cultivars and that, regardless of the stress applied, it causes activation of the same defence pathways.

\section{Materials and methods}

\section{Plant material and experimental design}

The experiment was carried out in Plant Breeding and Acclimatization Institute-National Research Institute (Division, Jadwisin), during two vegetation seasons from 25th of April to 10th of September. Two Polish potato cultivars, the drought-tolerant Gwiazda and drought-sensitive Oberon, both originated from the Zamarte Breeding Station in Poland, were used. Selected tubers with transverse diameters of 3-4 cm were pre-sprouted for 2 weeks before planting.

Plants were grown in a vegetation hall in $14 \mathrm{dm}^{3}$ pots filled with a thin layer of gravel on the bottom and $12 \mathrm{dm}^{3}$ of the universal vegetable soil substrate 'Hollas' (Agaris Polska Ltd., Poland) produced from peat with the addition of chalk at a pH range of 5.5-6.5. The density of pots was set at 4 per $\mathrm{m}^{2}$. Proper soil aeration was maintained in the pots. Additionally, in phase 20 of the BBCH-scale of plant development, MIS-3 (Intermag) fertilizer was applied. Pest and diseases control was carried out as followed: three times against Colorado beetles and four times against Phytophtora infestans. Plants were watered daily with an optimal tap water supply that is over $80 \% \mathrm{v} / \mathrm{v}$ of field water capacity. Water content (WC) in volumetric basis in soil pots was measured according to the following formula: volume water/ volume soil (Black 1965). Weather conditions during the years of study were monitored using a Weather Campbell Station (Campbell Scientific Inc.) located in close proximity, and a thermohygrograph placed between pots. Meteorological data of air temperature, the photosynthetically active radiation, and humidity were comparable in the years of study and favorable for potato development (Supp. 1).

Three weeks after the initiation of the tuberisation phase (56 DAP), plants were divided into 3 groups, each consisting of 6 plants. The first group of plants was subjected to soil drought (remained without irrigation, day/night temperature $22{ }^{\circ} \mathrm{C} / 18^{\circ} \mathrm{C}$ ), the second one to high temperature (day/night temperature $38{ }^{\circ} \mathrm{C} / 25^{\circ} \mathrm{C}$ ) and the third one was watered according to needs and at optimal temperature (control plants, day/night temperature $22^{\circ} \mathrm{C} / 18^{\circ} \mathrm{C}$ ). Stress application lasted 14 days and finished at 70 DAP. During this period, plants were placed in phytotron equipped with six Hortilux Schreder Lamps with Philips light bulbs of $1600 \mathrm{~W}$ each. Air humidity was in the range $65-70 \%$. WC under 14 days of soil drought reached $30 \%$ (v/v), and remained $80 \%(\mathrm{v} / \mathrm{v})$ in control and high temperature conditions. During the recovery period, after 14 days of stress treatment, WC reached control levels. 
Plant root material for proteomic research was collected on the 14th day of stress treatment (70 DAP). In the same day (70 DAP), samples for the leaf assimilation area, the dry mass of the leaf, the stem and the root were also collected. In order to establish the yield, plants previously subjected to stress were grown in optimal conditions until their full maturity (Photographs of plants in Supp. 2).

\section{Plant water status}

The mature and fully expanded leaves from the third level from the top of the plant, comparable in size, were sampled to assess relative water content (RWC). Leaves were cut from the plant, weighed immediately (fresh weight, FW), floated in dark for $24 \mathrm{~h}$ to achieve turgidity (saturated weight, SW), then oven-dried $\left(105^{\circ} \mathrm{C}\right)$ for $24 \mathrm{~h}$ and weighed again (dry weight, DW). The RWC of leaves was calculated according to the formula: $[(\mathrm{FW}-\mathrm{DW}) /(\mathrm{SW}-\mathrm{DW})] \times 100 \%$ (Li et al. 2017).

\section{Morphological measurements}

The assimilation area of the leaves (expressed in $\mathrm{cm}^{2}$ ) was determined using an LI-3100A area meter (LI-COR, USA) after the end of drought or high temperature period. The measurements were carried out in three replications.

Dry mass of leaves, stems and roots were assessed in a two-stage $24 \mathrm{~h}$ drying at $75^{\circ} \mathrm{C}$ and $105^{\circ} \mathrm{C}$ until constant weight was obtained.

Biomass reduction was calculated according to Li et al. (2017) (Supp. 3).The yield of tubers of all tested cultivars growing under optimal conditions (C), drought (D) and high temperature (HT) was given in grams per plant.

\section{Chlorophyll fluorescence measurements}

The kinetics of chlorophyll fluorescence were measured in the middle part of fully expanded and mature apical leaves of third- and fourth-level potato plants after 14 days of stress application on each combination (control, drought and high temperature). Measurements of the induction kinetics of fast chlorophyll fluorescence were taken with the Multifunctional Plant Efficiency Analyzer (Handy-PEA fluorimeter, Hansatech Instruments Ltd., Pentney, King's Lynn, Norfolk, England) and analysed with the software Pea Plus. Before measuring, plants were dark-adapted at least for $30 \mathrm{~min}$. Nine measurements per cultivar per treatment were performed (three technical repetitions for each three biological replications). Selected JIP-test parameters were calculated on the basis of fast fluorescence kinetics according to Strasser et al. (2004).

\section{Determination of the activities of antioxidant enzymes}

\section{Protein extraction}

Approximately $100 \mathrm{mg}$ of potato root samples were grinded in a mortar with liquid nitrogen, and $2 \mathrm{~cm}^{3}$ of an ice-cold $50 \mathrm{mM}$ potassium phosphate buffer $(\mathrm{pH} 7.0)$ containing $2 \mathrm{mM}$ 2-mercaptoethanol, $0.1 \mathrm{mM}$ EDTA, $0.5 \%$ (v/v) Triton X-100, and 2\% (w/v) polyvinylpyrrolidone. Homogenates were incubated on ice for $20 \mathrm{~min}$ and centrifuged at $16,000 \times g$ for $20 \mathrm{~min}$ at $4{ }^{\circ} \mathrm{C}$. The collected supernatants were used for antioxidant enzyme assays.

In all supernatants, the protein content was measured with Coomassie Brilliant Blue G-250 stain according to Spector (1978) with bovine serum albumin (BSA) as a protein standard.

\section{Measurements of antioxidant enzyme activity}

Superoxide dismutase (EC 1.15.1.1, SOD) activity was measured according to Kostyuk and Potapovich (1989). An assay buffer contained equal volumes of $67 \mathrm{mM} \mathrm{K} /$ Na phosphate buffer (pH 7.8) and $25 \mathrm{mM}$ EDTA, and was brought to $\mathrm{pH} 10.0$ by addition of TEMED. To $1 \mathrm{~cm}^{3}$ of assay buffer, $0.1 \mathrm{~cm}^{3}$ of $50 \times$ diluted supernatant was added. The reaction was initiated by adding $0.1 \mathrm{~cm}^{3}$ of $2.5 \mu \mathrm{M}$ quercetin in DMSO. The absorbance was measured at $406 \mathrm{~nm}$ immediately and after $20 \mathrm{~min}$ of reaction. SOD activity was expressed in arbitrary units (the concentration of SOD that inhibits superoxide-driven oxidation of quercetin by $50 \%$ ) per minute per $\mathrm{mg}$ of protein.

Catalase (EC 1.11.1.6, CAT) activity was measured according to the method based on Beers and Sizer (1952). To $0.9 \mathrm{~cm}^{3}$ of assay buffer $(0.05 \mathrm{M}$ phosphate buffer, $\mathrm{pH} 7.0), 0.5 \mathrm{~cm}^{3}$ of $30 \% \mathrm{H}_{2} \mathrm{O}_{2}$ was added. Absorbance at $240 \mathrm{~nm}$ was measured immediately after adding $0.1 \mathrm{~cm}^{3}$ of supernatant, and decrease in absorbance was recorded every $30 \mathrm{~s}$ for $4 \mathrm{~min}$. $\mathrm{H}_{2} \mathrm{O}_{2}$ extinction coefficient $43.6 \mathrm{M}^{-1} \mathrm{~cm}^{-1}$ was used to calculate CAT activity. Enzyme activity was expressed in micromoles of $\mathrm{H}_{2} \mathrm{O}_{2}$ per minute per $\mathrm{mg}$ of protein.

Guaiacol-type peroxidase (EC 1.11.1.7, GPOX) activity was estimated according to Chance and Maehly (1955). To $0.99 \mathrm{~cm}^{3}$ of $50 \mathrm{mM}$ acetic buffer (pH 5.6), $0.5 \mathrm{~cm}^{3}$ of $20 \mathrm{mM}$ guaiacol and $0.5 \mathrm{~cm}^{3}$ of $0.01 \mathrm{M} \mathrm{H}_{2} \mathrm{O}_{2}$ was added. The reaction was initialized by adding $10 \mathrm{~mm}^{3}$ of the supernatant. The absorbance was recorded at $485 \mathrm{~nm}$ for $5 \mathrm{~min}$, and measurements were taken every $30 \mathrm{~s}$. The GPOX activity was expressed in $\mu \mathrm{M}$ of tetraguaiacol $\left(\varepsilon=26.6 \mathrm{mM}^{-1} \mathrm{~cm}^{-1}\right)$ per minute per $\mathrm{mg}$ of protein. 


\section{Lipid peroxidation}

Lipid peroxidation was evaluated as a thiobarbituric acid reactive substances (TBARS) according to Heath and Packer (1968). $100 \mathrm{mg}$ of potato roots were homogenized in $0.5 \mathrm{~cm}^{3}$ of $10 \%$ TCA and then centrifuged at $10,000 \times g$ for $20 \mathrm{~min}$. To the collected supernatant, $1.5 \mathrm{~cm}^{3}$ of $0.5 \%$ TBA in 20\% TCA was added, and samples were heated for $25 \mathrm{~min}$ at $95{ }^{\circ} \mathrm{C}$. After cooling in an ice bath, samples were centrifuged at $3000 \times g$ for $15 \mathrm{~min}$. The absorbance was measured at 532, and $600 \mathrm{~nm}$ for correction. An extinction coefficient $155 \mathrm{mM}^{-1} \mathrm{~cm}^{-1}$ was used to quantify lipid peroxides and it was expressed as mmol TBARS per $\mathrm{g} F W$.

\section{Statistical analyses}

All data were subjected to statistical analyses. Two-way ANOVA, Student's t-test, Tukey's test were performed using MS-Excel 2010 and the Statistica 12 software. Applied p-values are given under the individual figures. All measurements were performed in 3 biological replicates $(n=3)$.

\section{Sample preparation for 2-DE analyses}

For the proteomic analyses, three samples from each combination of the experiment ( $\mathrm{n}=3$ biological replicates) were harvested. Approximately $500 \mathrm{mg}$ of potato root material per potato plant was collected and frozen in liquid nitrogen. The samples were then ground using a mortar and either stored at $-80{ }^{\circ} \mathrm{C}$ or used immediately for protein extraction. The total proteins were extracted for each of the three biological replicates according to Wang et al. method (2006). Samples of $150 \mathrm{mg}$ grounded potato root were transferred into $2 \mathrm{~cm}^{3}$ test tube and purified by washes with TCA/acetone, methanol and acetone. Afterwards, dried samples were thoroughly vortexed and incubated with a 1:1 mixture of phenol (pH 8.0, Sigma) and SDS buffer (0.1 M Tris-HCl, $\mathrm{pH} 8.0$ containing 30\% (w/v) sucrose, $5 \%(\mathrm{v} / \mathrm{v})$ b-mercaptoethanol and 2\% (w/v) SDS). After separation of phases by centrifuging, upper (phenol) phase was collected into a new tube. An overnight incubation with $0.1 \mathrm{M}$ ammonium acetate in $80 \%$ methanol at $-20{ }^{\circ} \mathrm{C}$ was performed to precipitate proteins from the mixture. Afterwards, samples were centrifuged and the supernatant was discarded. Pellets containing extracted proteins were thoroughly washed with pure methanol and $80 \%$ acetone, and air-dried. Purified proteins were dissolved in rehydration buffer containing $7 \mathrm{M}$ urea, $2 \mathrm{M}$ thiourea, $4 \%$ (w/v) CHAPS and $40 \mathrm{mM}$ DTT. Protein content was determined according to the Bradford method (1976) with bovine serum albumin (BSA) as a standard.

\section{D IEF/SDS-Page}

2DE gels were done according to Gietler et al. (2017). Sample of $120 \mu \mathrm{g}$ of purified proteins redissolved in $125 \mathrm{~mm}^{3}$ isoelectric focusing (IEF) buffer ( $7 \mathrm{M}$ urea, $2 \mathrm{M}$ thiourea, $4 \%$ (w/v) CHAPS, $40 \mathrm{mM}$ DTT, $0.5 \%$ (v/v) pH 4-10NL ampholytes, $0.002 \%(\mathrm{w} / \mathrm{v}$ ) bromphenol blue) was separated by 2D-PAGE. Proteins were subjected to IEF on $7-\mathrm{cm} \mathrm{pH}$ 4-10NL Immobiline DryStrips (Bio-Rad) using a Bio-Rad PROTEAN IEF focusing chamber flatbed electrophoresis system as recommended by the manufacturer. After IEF, strips were incubated for $10 \mathrm{~min}$ in equilibration buffer (50 mM Tris-HCl, pH 8.8, $6 \mathrm{M}$ urea, 30\% (v/v) glycerol, $2 \%$ (w/v) SDS, $0.002 \%(\mathrm{w} / \mathrm{v})$ bromophenol blue) with $1 \%(\mathrm{w} / \mathrm{v})$ DTT, and then for $10 \mathrm{~min}$ in equilibration buffer containing $2.5 \%(\mathrm{w} / \mathrm{v})$ iodoacetamide. Next, strips were sealed on the top of SDS-PAGE gels (4\% concentrating gel and $11 \%$ separating gel; $8.6 \times 6.8 \times 0.1 \mathrm{~cm})$ using $0.5 \%(\mathrm{w} / \mathrm{v})$ agarose in $0.1 \mathrm{M}$ Tris- $\mathrm{HCl} \mathrm{pH} 6.8$ containing $0.001 \%(\mathrm{w} / \mathrm{v})$ bromophenol blue. The SDS-PAGE was run in $50 \mathrm{mM}$ Tris- $\mathrm{HCl}$ buffer $\mathrm{pH} 6.8$, at constant amperage of $20 \mathrm{~mA} / \mathrm{gel}$ until the blue dye reached the bottom of the gel.

Protein spots were fixed in the gel for $2 \mathrm{~h}(15 \%(\mathrm{v} / \mathrm{v})$ ethanol and 10\% (v/v) acetic acid) and stained overnight with Coomassie brilliant blue G-250 (Merck, Darmstadt, Germany) in a solution containing $1 \%(\mathrm{w} / \mathrm{v})$ ortho-phosphoric acid and 10\% (w/v) ammonium sulphate.

\section{Quantitative gel analysis and protein identification by LC-MS/MS}

Coomassie-stained gels were scanned with Image Scanner III (GE Healthcare) and analysed using Delta2D software 4.4 (Decodon, Greifswald, Germany). Three gel replicates per cultivar and per treatment were compared, and spots were automatically detected. Minor corrections of gel disturbances were performed manually. To determine significant differences in spot patterns between the treatment and the control within a genotype, a Student's t-test based on the normalized relative spot volume was performed (p-value $\leq 0.05$ ). Only spots with a fold change greater than 1.5 were taken into consideration.

For liquid chromatography-tandem mass spectrometry (LC-MS/MS), isolated gel spots were destined in $100 \mathrm{~mm}^{3}$ of bleaching solution consisting of $50 \mathrm{mM}$ ammonium bicarbonate and ACN (1:1). Afterwards, gel pieces were incubated in $100 \mathrm{~mm}^{3}$ of pure ACN until they shrank and then in $50 \mathrm{~mm}^{3}$ of $10 \mathrm{mM}$ DTT in $100 \mathrm{mM}$ ammonium bicarbonate for Cys residues reduction. Cys residues alkalization was performed by incubation of dried gel in $50 \mathrm{~mm}^{3}$ of $50 \mathrm{mM}$ iodoacetamide in $100 \mathrm{mM}$ ammonium bicarbonate. Next, gel pieces were washed twice with $100 \mathrm{mM}$ ammonium bicarbonate and dried in pure ACN. Afterwards, trypsin in-gel 
digestion was performed $\left(10 \mathrm{ng} / \mathrm{mm}^{3}\right.$ in $25 \mathrm{~m} \mathrm{M}$ ammonium bicarbonate) at $37{ }^{\circ} \mathrm{C}$ overnight. Obtained peptides were extracted from gels with $0.1 \%$ TCA and $2 \%$ ACN solution.

Significantly differential proteins were identified commercially by LC-MS/MS analysis in Mass Spectrometry Lab, Institute of Biochemistry and Biophysics, Polish Academy of Sciences (Poland).

Protein identification was performed using Matrix Science server across Viridiplantae NCBI database (5.11.2015, 57,412,064 sequences; 20,591,031,683 residues) with peptide mass tolerance $\pm 20 \mathrm{ppm}$, fragment mass tolerance $\pm 0.1 \mathrm{Da}$ and allowed missed cleavage $\leq 1$. Obtained results were evaluated on the basis of MASCOT score, percentage of coverage, number of identified unique sequences, as well as protein mass and pI. The best-fit protein was considered to be correctly identified. The mass spectrometry proteomics data have been deposited to the ProteomeXchange Consortium via the PRIDE (Perez-Riverol et al. 2019) partner repository with the dataset identifier PXD020259 and 10.6019/PXD020259.

\section{Protein interaction}

The prediction of functional networks of identified proteins was performed using STRING software version 11.0 accessible online (https://string-db.org), a database of known and predicted protein interactions (Szklarczyk et al. 2011) containing 24,584,628 proteins from 5090 organisms, and $3,123,056,667$ interactions. Multiple protein search was performed for all proteins differential for every stress and cultivar. A database for Solanum tuberosum was searched, and confidence level for protein interaction was set at high level (0.700).

\section{Results}

\section{Morpho-physiological responses of potato plants to soil drought or high temperature}

A 14-day period of withholding watering of potato plants, three weeks after the initiation of the tuberisation phase, resulted in a significant decline in the water content in leaves measured as RWC (relative water content in \%) in both examined cultivars (Table 1). Comparison of RWC in control plants growing under optimal conditions of both cultivars did not show any significant differences. At the end of soil drought, RWC decreased about $40 \%$ in cultivar Gwiazda, and 50\% in cultivar Oberon. As expected, a strong wilting phenotype was observed in the cultivar Oberon. The phenotypic observation in both cultivars supported the earlier finding (Boguszewska-Mańkowska et al. 2018) that the avoidance strategy of drought resistance is better developed in the cultivar Gwiazda (Supp. 2). High temperature impact on RWC was significantly milder. There was no significant difference between RWC of leaves of control plants of both cultivars and those treated with high temperature (Table 1).

Agricultural definition of drought tolerance is based on maintenance of tuber yield under drought conditions (Obidiegwu 2015). In the investigated cultivars, tuber yield was more affected by the applied soil drought then high temperature treatment (Table 1). The decrease of tuber yield, assessed as tuber fresh mass at the end of vegetation period, was more pronounced by soil drought than the tuber yield loss caused by high temperature in both cultivars. Moreover, a decrease of tuber yield in response to stresses was significantly higher in cultivar Oberon, than in cultivar Gwiazda. In response to soil drought, potato tuber yield dropped about $8.4 \%$ in cultivar Gwiazda, and about $44 \%$ in Oberon.
Table 1 Changes in the leaf relative water content (RWC in $\%$ ), leaf assimilation area (LAA) and leaf, tuber yield, stem and root dry mass of two potato cultivars growing under optimal conditions (C), subjected to 14 days of soil drought (D) or high temperature (HT)

\begin{tabular}{|c|c|c|c|c|c|c|c|}
\hline \multirow[t]{2}{*}{ Cultivar } & \multirow[t]{2}{*}{ Treatment } & \multirow[t]{2}{*}{ RWC (\%) } & \multirow{2}{*}{$\begin{array}{l}\text { Leaf assimila- } \\
\text { tion area } \\
\left(\mathrm{cm}^{2}\right)\end{array}$} & \multirow{2}{*}{$\begin{array}{l}\text { Fresh mass }(\mathrm{g}) \\
\text { Tuber yield }\end{array}$} & \multicolumn{3}{|c|}{ Dry mass (g) } \\
\hline & & & & & Leaf & Stem & Root \\
\hline \multirow[t]{3}{*}{ Gwiazda } & $\mathrm{C}$ & $89,5 \mathrm{a}$ & $7990 \mathrm{a}$ & $1363 \mathrm{a}$ & $52.46 \mathrm{a}$ & $48.30 \mathrm{ab}$ & $1.31 \mathrm{~b}$ \\
\hline & $\mathrm{D}$ & $53,7 \mathrm{c}$ & $2249 \mathrm{e}$ & $1249 \mathrm{ab}$ & $32.8 \mathrm{c}$ & $39.34 \mathrm{c}$ & $1.11 \mathrm{c}$ \\
\hline & HT & $88,0 \mathrm{ab}$ & $5544 \mathrm{c}$ & $1289 \mathrm{ab}$ & $41.7 b$ & $50.45 \mathrm{a}$ & $1.25 \mathrm{bc}$ \\
\hline \multirow[t]{3}{*}{ Oberon } & $\mathrm{C}$ & $90,5 \mathrm{a}$ & $6568 b$ & $1314 \mathrm{ab}$ & $39.09 \mathrm{~b}$ & $40.06 \mathrm{c}$ & $1.69 \mathrm{a}$ \\
\hline & $\mathrm{D}$ & $41,5 \mathrm{~d}$ & $1533 f$ & $739 \mathrm{c}$ & $23.20 \mathrm{~d}$ & $30.85 \mathrm{~d}$ & $1.00 \mathrm{~d}$ \\
\hline & HT & $82,1 b$ & $3668 d$ & $1105 d$ & $30.46 \mathrm{c}$ & $38.5 \mathrm{c}$ & $1.64 \mathrm{a}$ \\
\hline \multicolumn{8}{|c|}{ Statistical significance $(\operatorname{Pr}>F)^{a}$} \\
\hline Treatment $(\mathrm{D}, \mathrm{HT})$ & & $* *$ & $* *$ & $* *$ & $* *$ & $* *$ & $* *$ \\
\hline Cultivar (C) & & $* *$ & $* *$ & $* *$ & * & * & $* *$ \\
\hline C x D x HT & & $* *$ & $* *$ & $* *$ & $*$ & * & $* *$ \\
\hline
\end{tabular}

The letters (a-e) denote the statistical significance (Tukey's HSD test) of the differences between cultivar/ stress treatment

${ }^{\text {a }}, * *$ indicate significance at $\mathrm{p}=0.05$ and 0.01 
Similar tendency was noticed in response to high temperature, where yield losses reached approximately $5 \%$ in cultivar Gwiazda and $16 \%$ in Oberon (Table 1). The presented results confirm the earlier findings that cultivar Gwiazda is more tolerant to soil drought than cultivar Oberon (Boguszewska-Mańkowska et al. 2018; Pieczyński et al. 2018). Additionally, cultivar Gwiazda is also more tolerant to high temperature, when compared to cultivar Oberon.

Drought tolerant cultivar Gwiazda developed higher leaf area in comparison to cultivar Oberon (Table 1). Drought treatment reduced the leaf assimilation area more than high temperatures. At the end of soil drought, the leaf area was reduced by about $77 \%$ and $72 \%$ in Oberon and Gwiazda, respectively. High temperatures reduced leaf area by about $30 \%$ and $45 \%$ in drought-tolerant and sensitive cultivars, respectively.

Dry mass of leaves, stem and roots significantly decreased under drought, more so in drought sensitive (Oberon) than in drought tolerant (Gwiazda) cultivar. Reduced leaf area and ability of tolerant cultivar (Gwiazda) to form a large shoot biomass has been shown to be an effective insurance against soil drought (Obidiegwu 2015). It should be underlined that the tendency for an increased root/shoot ratio under soil drought may contribute to drought tolerance of cultivar Gwiazda. High temperature only reduced the dry weight of leaves in both cultivars, independently of their sensitivity to soil drought.

Another strategy to confer tolerance to both types of stresses is the enhancement of the reactive oxygen species scavenging system. Antioxidant responses of roots were assessed on the basis of catalase (CAT), peroxidase (GPOX), superoxide dismutase (SOD) activities and lipid peroxidation (LP) (Fig. 1a-d). The catalase activity (Fig. 1a) was not detected in the roots of control plants of both cultivars. The response of enzyme activity was stress- and cultivardependent. High temperature resulted in a higher activity of CAT (Fig. 1a) and GPOX (Fig. 1b) but lowered activity of SOD (Fig. 1c). The response of investigated enzyme
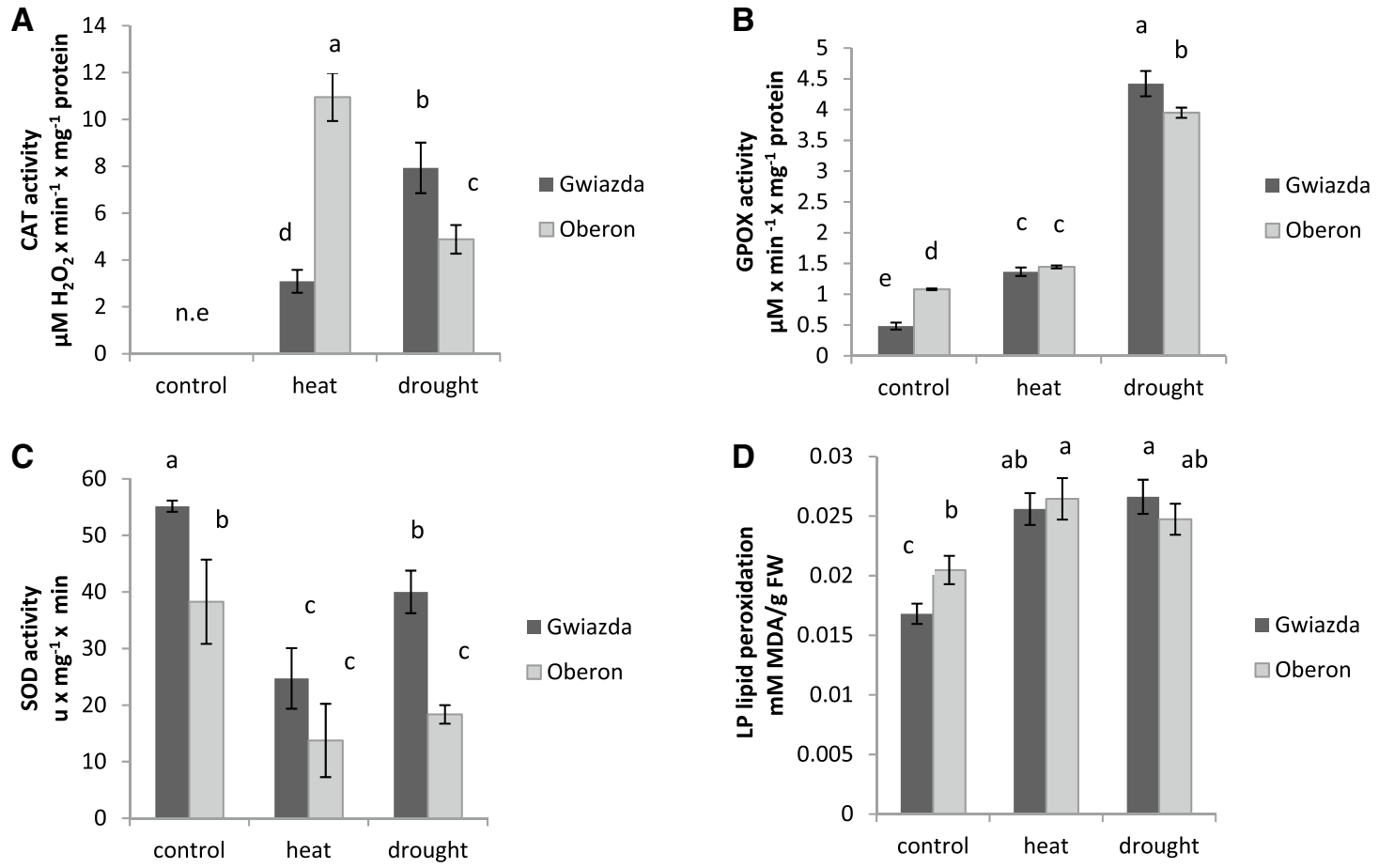

$\begin{array}{lcccc}\text { Statistical significance }(\mathrm{Pr}>\mathrm{F}) & \mathrm{CAT} & \mathrm{GPOX} & \mathrm{SOD} & \mathrm{LP} \\ \text { Treatment }(\mathrm{D}, \mathrm{HT}) & * * & * * & * * & * * \\ \text { Cultivar (C) } & * * & - & * * & - \\ \text { C x D x HT } & * * & * * & - & * *\end{array}$

Fig. 1 The activities of antioxidant enzymes (a-c) and lipid peroxidation (d) in the roots of potato cultivars subjected to 14-days of soil drought or high temperature. The activity of a catalase (CAT), b guaiacol peroxidase (GPOX), c superoxide dismutase (SOD), and d lipid peroxidation (LP) in potato roots of Gwiazda (tolerant) and Oberon (sensitive) cultivars. The letters $(a-e)$ denote the statistical signifi- cance (Tukey's HSD test) of the differences between cultivar/stress treatment. Different letters mean significant differences at $\mathrm{p}>0.05$, n.e not estimated by this method. At the bottom two-way ANOVA is presented, where $*$, $* *$ indicate significance accordingly at $\mathrm{p}=0.05$ and 0.01 , n.s not significant 
activity to soil drought was quite similar to the root enzyme response to high temperature. However, some differences in the cultivar response have been observed. The activity of CAT and GPOX in drought-tolerant Gwiazda roots was higher in response to soil drought but decreased under high temperature. Similarly, the activity of GPOX was higher in Gwiazda (tolerant cultivar) under soil drought in comparison to sensitive Oberon, but remained the same in both cultivars treated with high temperature.

As ROS oxidize all types of cellular components (lipids, proteins and DNA), the changes in lipid peroxidation during soil drought or high temperature was assessed on the basis of thiobarbituric acid reactive substances (TBARS) content, which is routinely used as an index of lipid peroxidation under stress conditions (Fig. 1d). The TBARS content was higher in Oberon, sensitive cultivar for roots of control plants. In response to both soil drought and high temperature, the content of TBARS increased in roots of both cultivars and was independent of cultivar tolerance and kind of stress applied.

In order to evaluate the photosystem (PS) II activity and its response to stress conditions, one of the recent methods of data interpretation has been applied. Multiple parameters of JIP test in relation to each other were displayed as radar plot (Fig. 2). It is interesting to note that the performance index (PI total), the most sensitive parameter for stress detection and quantification, revealed a similar decrease for the high temperature treated conditions and drought-sensitive cultivar, whereas it differentiated between drought-tolerant and sensitive cultivars. This finding confirms our previous results (Boguszewska-Mańkowska et al. 2018) and allows us to conclude that the PI seems to be a good indicator for plant drought tolerance. Other parameters like Pi Inst, dVG/dto, $\mathrm{dv} / \mathrm{dto}, \mathrm{Dlo} / \mathrm{RC}$ also differentiate between drought and heat tolerant and sensitive cultivars (Fig. 2).

\section{Analysis of differentially abundant proteins (DAPs) in root proteome under drought or high temperatures}

Potato exposure to soil drought or high temperatures resulted in the changed presence of some proteins in potato roots (Fig. 3). There were 18 spots differentiating the control and the drought-stressed roots of the tolerant cultivar (Table 2A) and 13 spots differentiating the control and the drought-stressed roots of the sensitive cultivar (Table 2B). In response to high temperature treatment, 21 protein spots were detected as DAPs in the tolerant cultivar (Table 2C) and 14 spots in the sensitive cultivar (Table 2D). The majority of the proteins in root proteome induced by soil drought were abundant in both cultivars i.e. in the tolerant potato cultivar, the abundance of 10 proteins increased, whereas in the sensitive cultivar, 9 proteins were more abundant. The

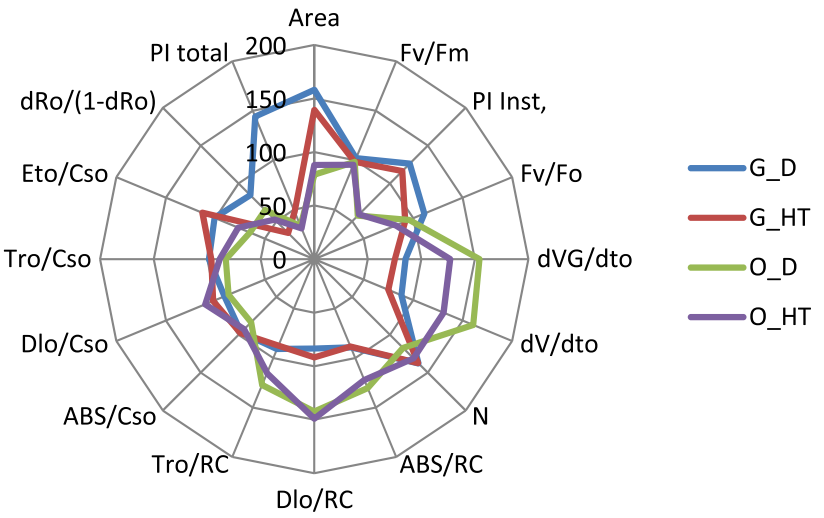

Fig. 2 "Spider plot" a of selected JIP test parameters. The average values (shown as \% of the corresponding value of the control) in different genotypes of potato upon soil drought (D) and high temperature (HT). $G$ cultivar Gwiazda, $O b$ cultivar Oberon, Area $(A M)$ area above the OJIP curve between Fo and Fm and the Fm, $F v / F m$ maximum quantum efficiency of PSII photochemistry, PI Inst PERFORMANCE index of PSII based to absorption, Fv/Fo efficiency of the water-splitting complex on the donor side of PSII, $d V G / d t o$ initial slope of chlorophyll fluorescence rise, $d V / d t o$ speed of closing reaction centers of PSII, $N$ the number indicating how many times QA is reduced while the fluorescence reaches its maximal value (number of QA redox turnovers until $\mathrm{Fm}$ is reached), $A B S / R C$ absorption flux per $\mathrm{RC}, D I o / R C$ dissipated energy flux per reaction center, $T R o / R C$ trapping flux leading to QA reduction per RC, ABS/Cso obtained from measurements as initial fluorescence, Dlo/Cso Dissipated energy flux per $\mathrm{CS}$ at $\mathrm{t}=0, E t o / C s o$ electron transport flux further than QA- per cross section, $d R o /(1-d R o)$ maximum quantum yield of primary photochemistry, PI total performance index: the performance of electron flux to the final PSI electron acceptors

differential sensitivity of the investigated cultivars to drought was also associated with a down-regulation of 8 proteins in the tolerant cultivar and 4 proteins in the sensitive one (Table 2a-d). All of these protein spots were excised and successfully identified by LC-MS/MS analysis followed by MASCOT database searches of Viridiplantae in the NCBI database. Detailed information concerning the proteins identified in potato roots subjected either to soil drought or high temperature, i.e. protein accession number, identification scores, molecular weight (MW) and isoelectric points (pI), etc. is presented in Table 2a-d. Additional information, such as unique peptide sequences, and GO classification is presented in Supp. 4 (A-E).

The functional distribution of identified DAPs has been changed in response to soil drought in both sensitive and tolerant cultivars. In Gwiazda (tolerant) roots, these proteins are mainly associated with energy and carbohydrate metabolism and defence/detoxification processes (Fig. 4a). However, the share of differential proteins involved in defence and detoxification in the sensitive (Oberon) cultivar was almost two times higher than in tolerant plants and about two times lower in energy and carbohydrate metabolism (Fig. 4a). High temperature changed the share of proteins 


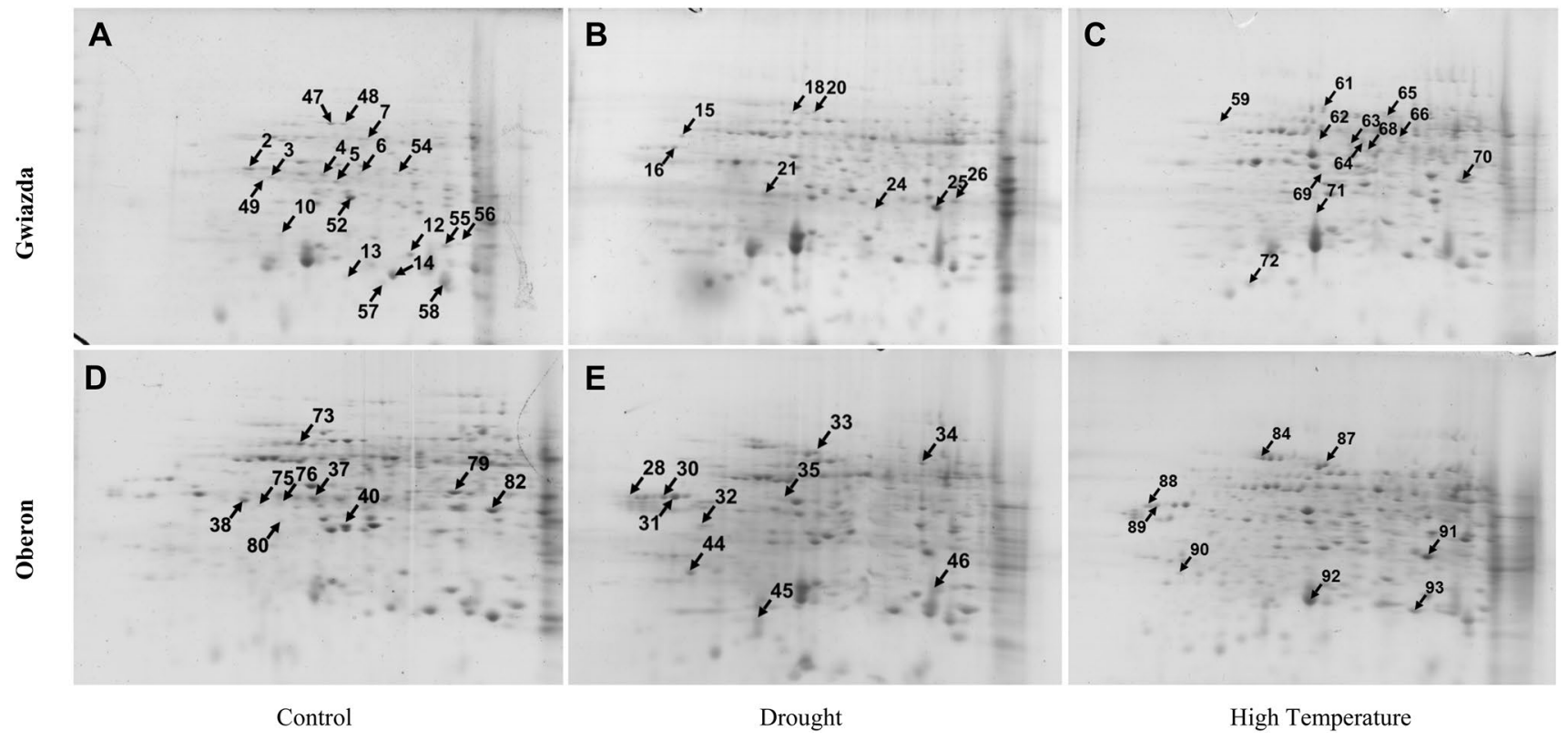

Fig. 3 Protein expression patterns with indication of differentially abundant proteins in the roots of potato cultivars subjected to drought and high temperature

involved in cell wall synthesis which was $15 \%$ in the tolerant cultivar. A similar change did not occur in the sensitive genotype. In both cultivars, the main share of proteins was involved in energy and carbohydrate metabolism and in defence/detoxification processes (Fig. 4b).

Comparison of functional distribution of identified differentially abundant proteins in the tolerant (Gwiazda) cultivar indicated that changes in the share of proteins involved in energy and carbohydrate metabolism and in defence/ detoxification in response to drought or high temperature is very similar. Differences are visible in the percentage of proteins involved in nucleic and amino acid metabolism (6\% in response to drought and $14 \%$ in response to high temperature) and in cell wall proteins (23\% in response to drought and $10 \%$ in response to high temperature). On the other hand, functional distribution of identified DAPs in the sensitive (Oberon) cultivar was different in both stresses. In response to drought, differentially abundant proteins were involved mainly in defence and detoxification (77\%), while in response to high temperature, they were involved in energy and carbohydrate metabolism (50\%) and defence/ detoxification (43\%). Among drought-responsive proteins, cell wall proteins were identified but they were not expressed in response to high temperature. The opposite was observed in high temperature treated potato plants, in which proteins involved in nucleic and amino acid metabolism were identified.

Comparison of changes in protein abundance showed that in response to soil drought, most of the differential upregulated proteins in the sensitive cultivar (Oberon) were involved in defense and detoxification, whereas in roots of the tolerant cultivar, only four proteins in this functional category were more abundant and three were less abundant. Moreover, in the tolerant (Gwiazda) cultivar, four proteins involved in energy and carbohydrate metabolism increased in abundance and two decreased, while in the sensitive (Oberon) cultivar, only one protein in this category was less abundant (Fig. 4a). Similar changes in protein abundance were observed in temperature treated roots (Fig. 4b). Among the drought-responsive proteins in roots of the tolerant (Gwiazda) cultivar, many of the DAPs are those involved in glycolysis or gluconeogenesis e.g. enolase, triosephosphate isomerase, fructose-bisphosphate aldolase, whereas in roots of the drought sensitive potato cultivar, these proteins have not been found. High temperature resulted in the lower abundance of proteins involved in glycolysis such as phosphoglycerate kinase, fructose-bisphosphate aldolase, and glyceraldehyde-3-phosphate dehydrogenase in roots of the sensitive cultivar.

\section{Dynamics of changes in protein profiles in response to soil drought or high temperature}

A principal component analysis (PCA) based on the proteome characterization allows discriminating between the two potato cultivars, as depending on proteome reaction to soil water deficiency or high temperature treatment.

PCA of obtained proteome maps proved that protein profiles in the tolerant (Gwiazda) cultivar have changed upon stress treatment. The first two components of the PCA 
accounted for $60.227 \%$ of the total variation of the original data, and the first three components accounted for $73.850 \%$ of the variation among samples. PC1 explained $36.323 \%$ of the variance, whereas PC2 accounted for $23.904 \%$ of the variance. In comparison to control plants, shoots treated with heat and drought have different profiles according to PC1, however, both types of stresses had similar PC2 values that differed significantly from the PC2 value of the control plants profile. For Oberon cultivar, the first two components of the PCA accounted for $59.184 \%$ of the total variation of the original data, and the first three components accounted for $72.297 \%$ of the variation. PC1 explained $32.760 \%$ of the variance, and PC2 accounted for $26.424 \%$ of the variance. PCA of Oberon cultivar showed that control plant had different $\mathrm{PC} 1$ value than stressed plant, however, $\mathrm{PC} 1$ was not differential to profiles of stressed shoots. However, all of the combinations had different PC2 values, therefore, they formed separate groups (Fig. 5).

PCA results suggest that the response of root proteome to stresses is far from random, as specific proteins patterns developed in reaction to drought and high temperature in both cultivars.

\section{Common and unique drought- and high temperature-responsive proteins}

Venn diagram analysis revealed that some of the DAPs were common for cultivars for both stresses (Fig. 6). In the Gwiazda (tolerant) cultivar, less abundant NAD(P)H dehydrogenase (quinone), and V-type proton ATPase catalytic subunit, RuBisCO large chain, and rubber elongation factor protein increased in abundance and were common for both drought and high temperature stresses, whereas in the Oberon (sensitive) cultivar, the only common DAP under both stresses was 14-3-3 protein 10 OS. The abundance of two proteins, namely fructose-bisphosphate aldolase and remorin OS increased in roots of the drought-tolerant and sensitive cultivar subjected to high temperature. Fructokinase and lactoylglutathione lyase are drought-responsive proteins in roots of the sensitive cultivar (Oberon) and high temperature-responsive proteins in roots of the tolerant cultivar (Gwiazda). The more abundant heat shock $70 \mathrm{kDa}$ protein was absent under both stresses in the drought-sensitive cultivar, whereas less abundant alpha-1,4-glucan-protein synthase [UDP-forming] was absent only in the susceptible Oberon cultivar subjected to high temperature.

The abundance of ten proteins identified in roots of drought-treated tolerant cultivar, fourteen proteins in roots of tolerant cultivar under high temperature, eight proteins in roots of drought sensitive cultivar and ten proteins in roots of high temperature sensitive cultivar seems to be related to the level of potato plants tolerance either to soil drought or high temperature stress factor applied.
A

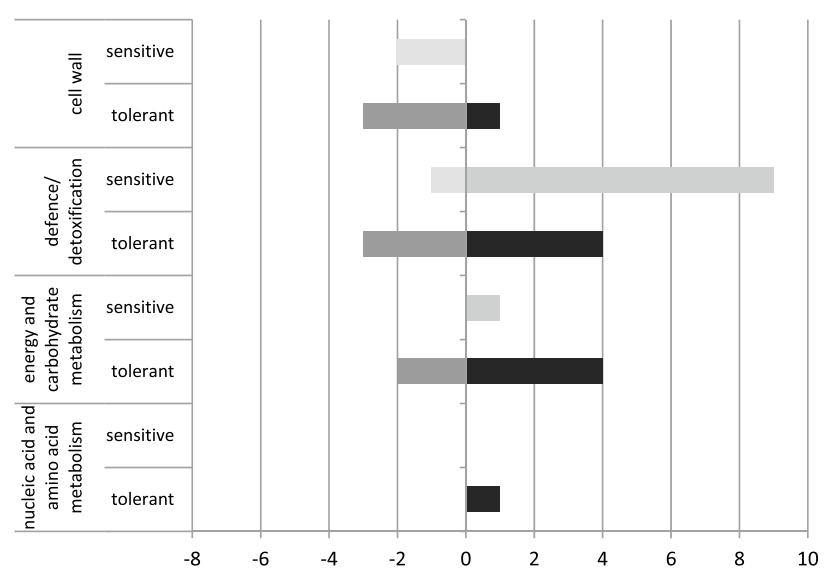

B

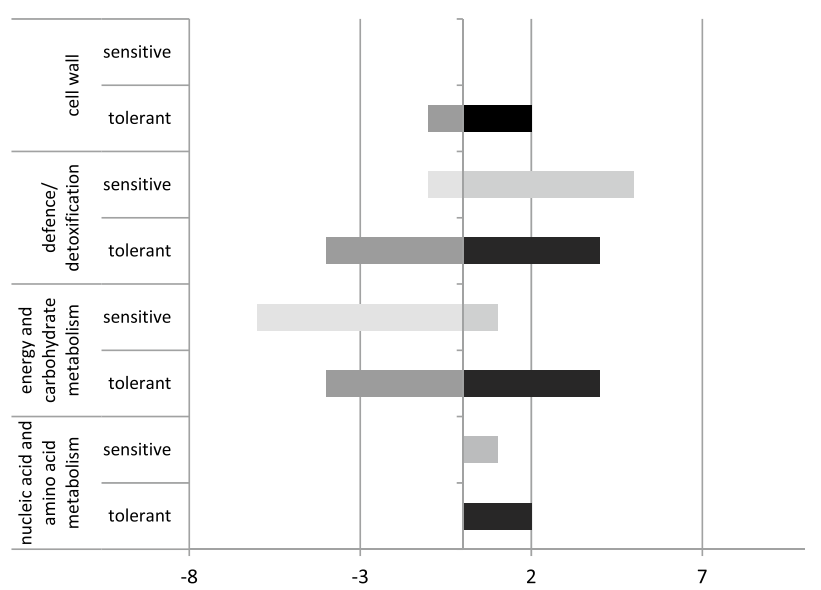

Fig. 4 Number of up and down-regulated differentially abundant proteins in tolerant (Gwiazda) and sensitive (Oberon) cultivars in response to drought (a) and high temperature (b)

\section{Functional interaction network of differentially abundant proteins}

The prediction of functional networks of identified DAPs in soil drought and high temperature tolerant and sensitive potato cultivars was performed using STRING software (https://string-db.org). In the tolerant cultivar (Gwiazda) subjected to soil drought or high temperature, almost all identified proteins involved in energy and carbohydrate metabolism were a part of the network together with a few proteins involved in different functional groups. In the sensitive (Oberon) cultivar, the protein network of roots was not very extensive upon soil drought and contained just eight proteins that were not strongly associated with each other. However, in plants of the sensitive (Oberon) cultivar subjected to high temperature, the observed network was extended and consisted of strongly connected proteins, but 


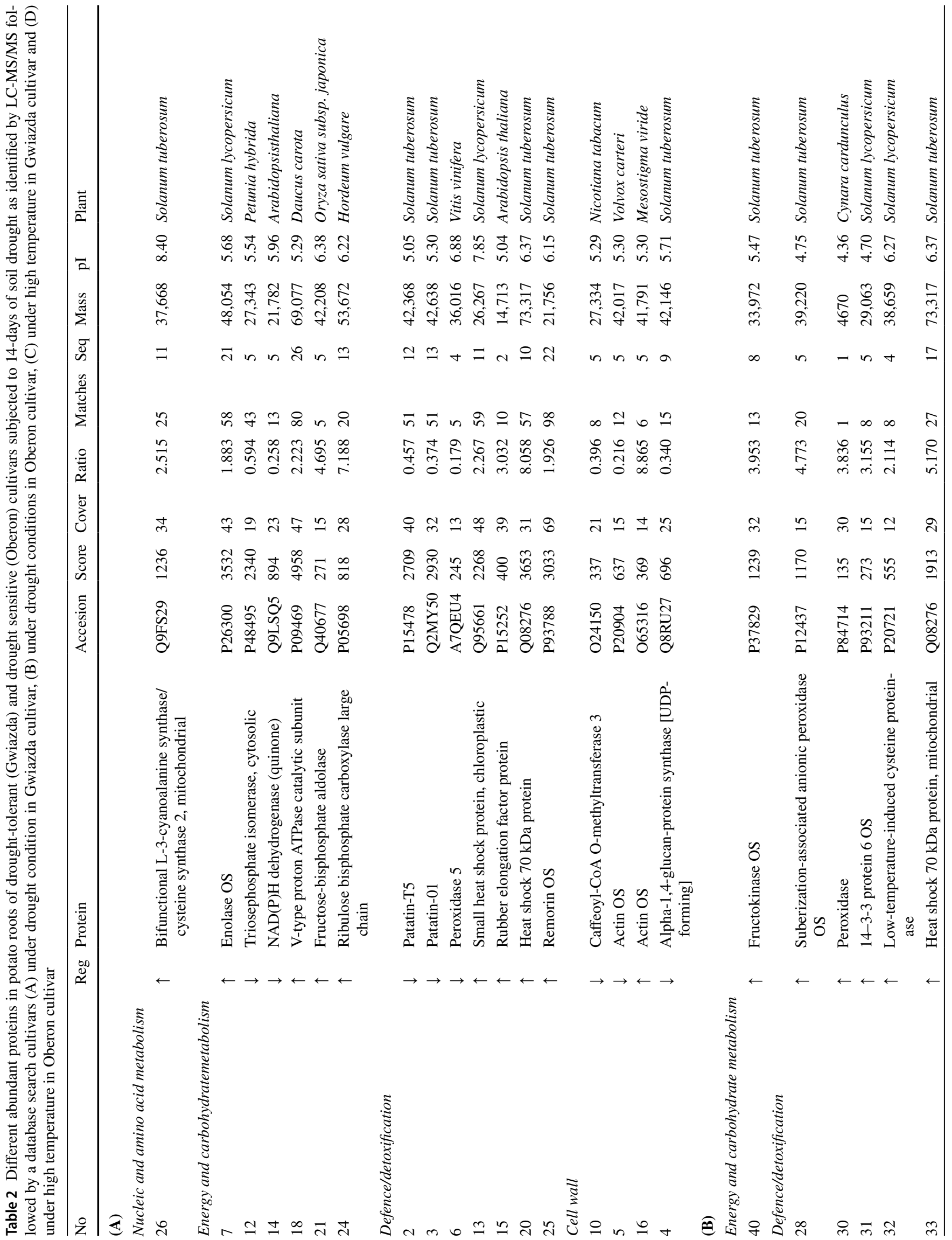




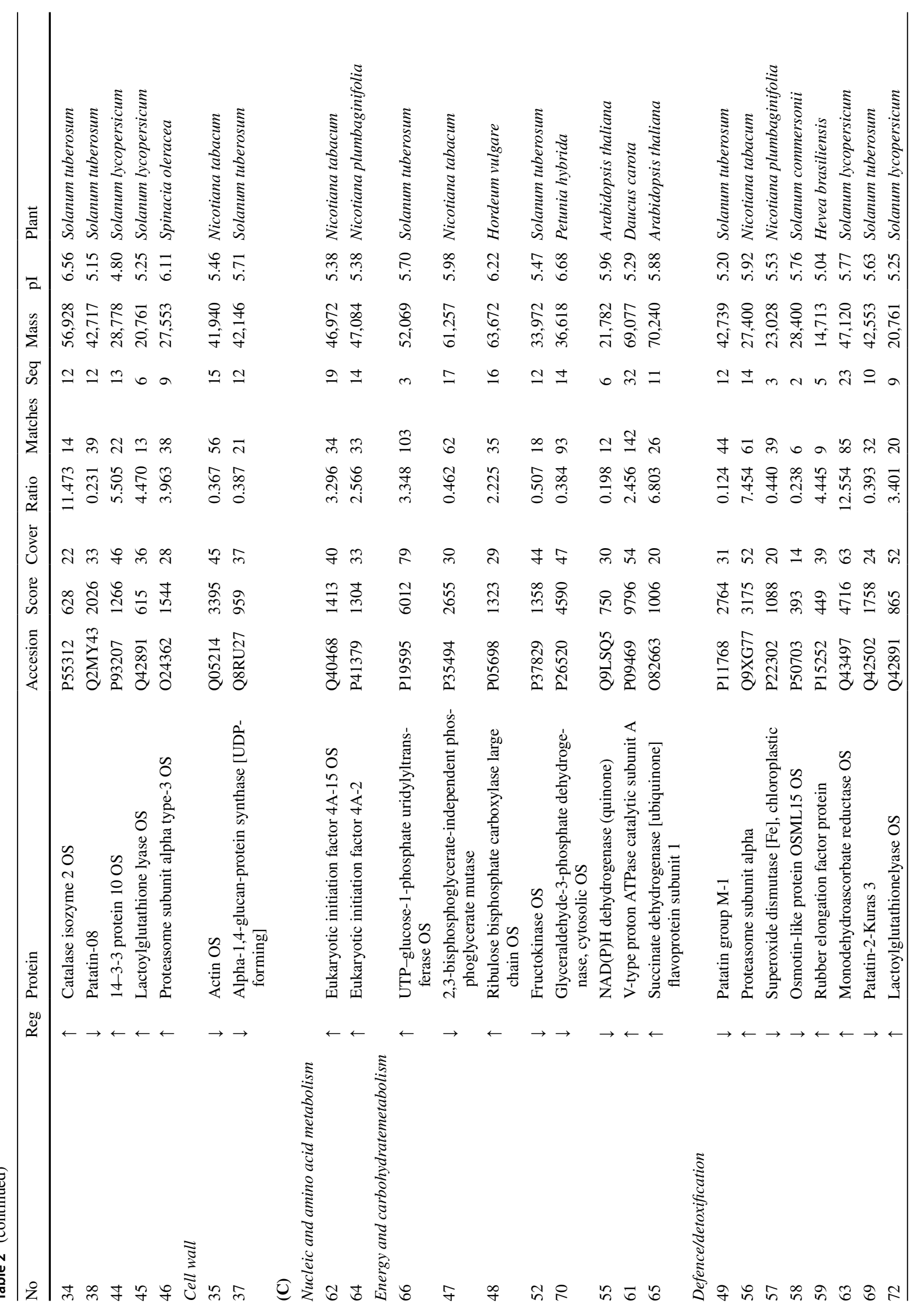




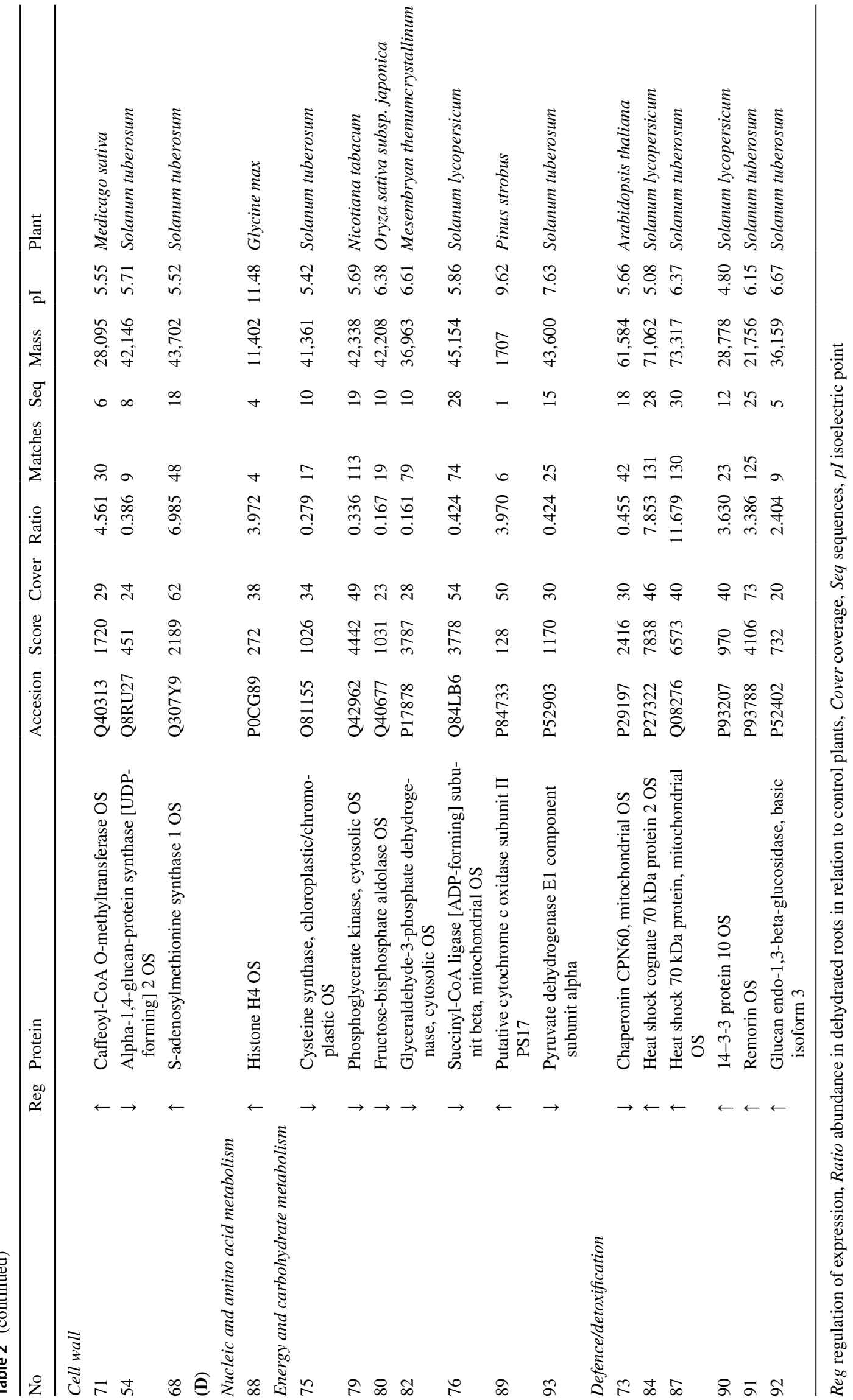


abundance of most of them, especially those involved in energy and carbohydrate metabolism, decreased in response to unfavourable environmental conditions (Fig. 7).

\section{Discussion}

The phenotype of a root system is of paramount importance in dehydration tolerance (Watt et al. 2008). Potato plants in general have relatively shallow root systems that make it difficult to reach the water contained in deeper soil layers. Large rooted potato genotypes have a smaller reduction in yield and shoot dry weight compared to genotypes with smaller roots (Deguchi et al. 2010). However, the sensitive cultivar (Oberon) has shown higher yield decrease in response to drought, despite its larger root system. When exposed to water shortage, the tolerant cultivar (Gwiazda) had larger root fresh mass than the sensitive one indicating that the observed changes of root architecture may improve plant tolerance, as it was previously suggested (Zarzyńska et al. 2017).

The drought sensitive (Oberon) cultivar has shown higher tuber yield loss in response to high temperature, although RWC of both cultivars has been comparable in leaves of plants growing under optimal growth conditions (control), and under high temperature. The response to heat was more visible in above-ground part of the plant, especially in lowering the leaf assimilation surface, which was nearly $34 \%$ lower in the sensitive cultivar.

The maintenance of active leaf assimilation area and higher RWC allowed the potato to carry out efficient photosynthesis. In fact, the sensitive cultivar (Oberon) showed decreased parameters of JIP test and photosynthetic $\mathrm{CO}_{2}$ exchange (Boguszewska-Mańkowska et al. 2018). Although

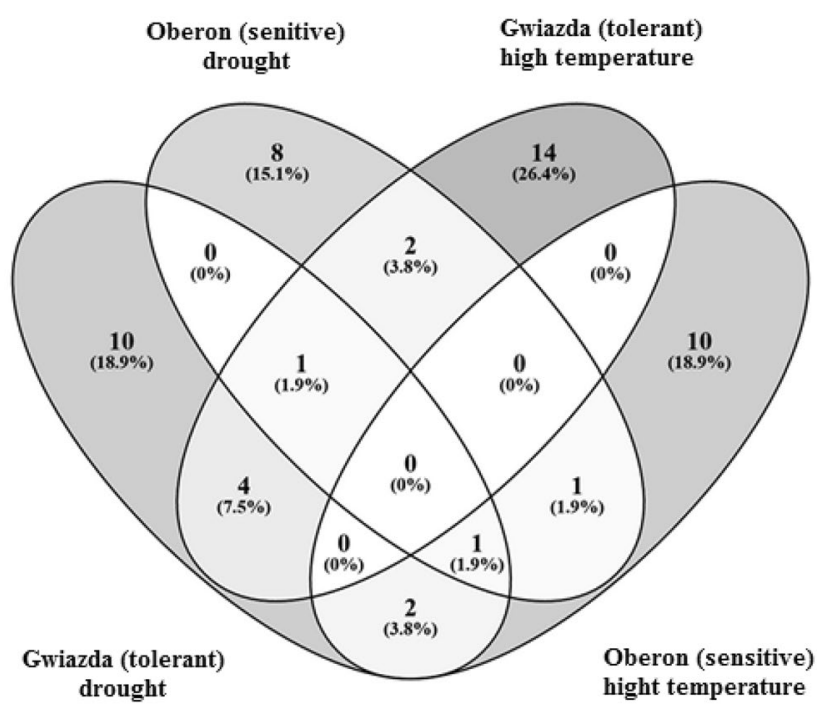

Fig. 6 Venn diagram analysis showing number and percentage of differentially abundant proteins that overlapped between two potato cultivars in tolerant (Gwiazda) and sensitive (Oberon) cultivars and two stresses drought and high temperature

photosynthetic performance under drought or high temperature reduced the tuber yield, the mechanism of this phenomenon is still not well understood (Dahal et al. 2019).

The observed differences in chlorophyll fluorescence parameters do not appear to be primary sites of damage of photosynthetic apparatus (Cornic and Massaci 1996). The enhanced production of ROS and activation of hydrolytic enzymes results in oxidation and oxidative destruction of proteins, nucleic acids and membrane lipids (Mittler 2002). Oxidative damage occurrence evidenced by TBARS content indicates that the intensity of lipid peroxidation in potato

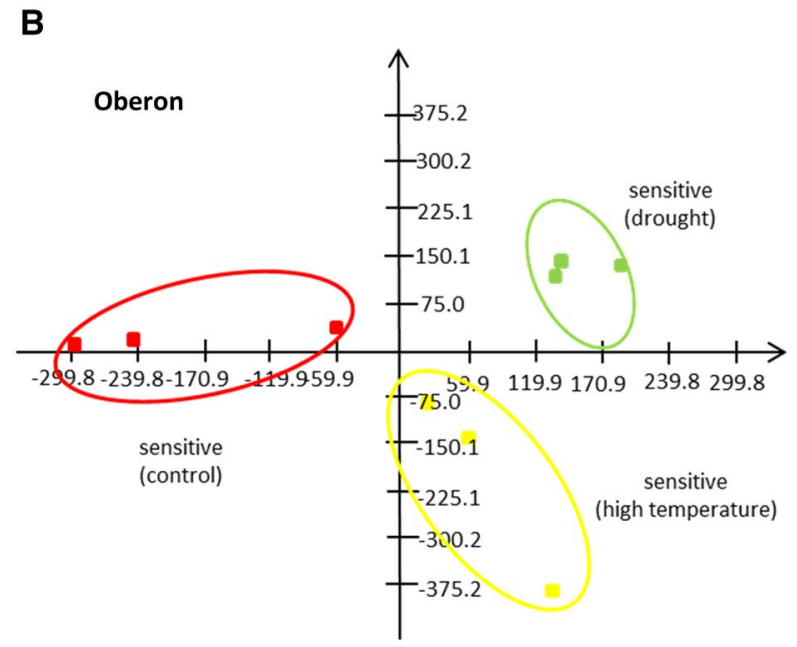

Fig. 5 PCA analysis of 2D-PAGE gels of roots of two potato cultivars in tolerant (Gwiazda) (a) and sensitive (Oberon) (b) subjected to drought and high temperature stress. Red—control, green—drought, yellow—high temperature 
roots was not related to the kind of stress nor the cultivar sensitivity to the stress factor.

Decreased water availability in potato roots resulted in the increased activity of CAT and GPOX, more so in the tolerant than the sensitive cultivar, suggesting that an antioxidant system is enhanced. However, the activity of SOD, an enzyme related to redox homeostasis, decreased in roots subjected to soil drought or high temperature and the observed drop was more pronounced in the sensitive cultivar than in the tolerant one. These data suggest that similar antioxidant mechanisms are activated in potato roots, tubers and leaves under soil drought and high temperature (Boguszewska et al. 2010). However, cultivar-dependent differences were noticed in terms of CAT, SOD and GPOX activities in potato organs (Boguszewska et al. 2010; Ahmad et al. 2010; Kaur et al. 2020).

\section{Abundance of proteins involved in cell wall synthesis decreased upon drought and high temperature}

Plant growth requires intensive water uptake and permanent cell wall expansion to expand cells. In parallel with cellulose and hemicellulose, pectins have been shown to play a key part in controlling cell wall structure in response to drought and heat stress. A number of studies report that cellulose and lignin biosynthesis can be altered in response to water deficiency (Piro et al. 2003; Bray 2004). The decreased abundance of caffeoyl-CoA 3-O-methyltransferase (EC 2.1.1.104) in response to drought (spot 10) and increased abundance in high temperature treated roots (spot 71) of the tolerant Gwiazda cultivar, engaged in the lignin biosynthesis, suggests lowered intensity of lignin synthesis (Tu et al. 2010).

S-adenosylmethionine synthetase (EC 2.5.1.6), catalyzing the biosynthesis of S-adenosylmethionine, is also involved in the ethylene-mediated inhibition of root growth and alteration of the cell wall and polymer structures in rice roots. Increased abundance of this enzyme (spot 68)

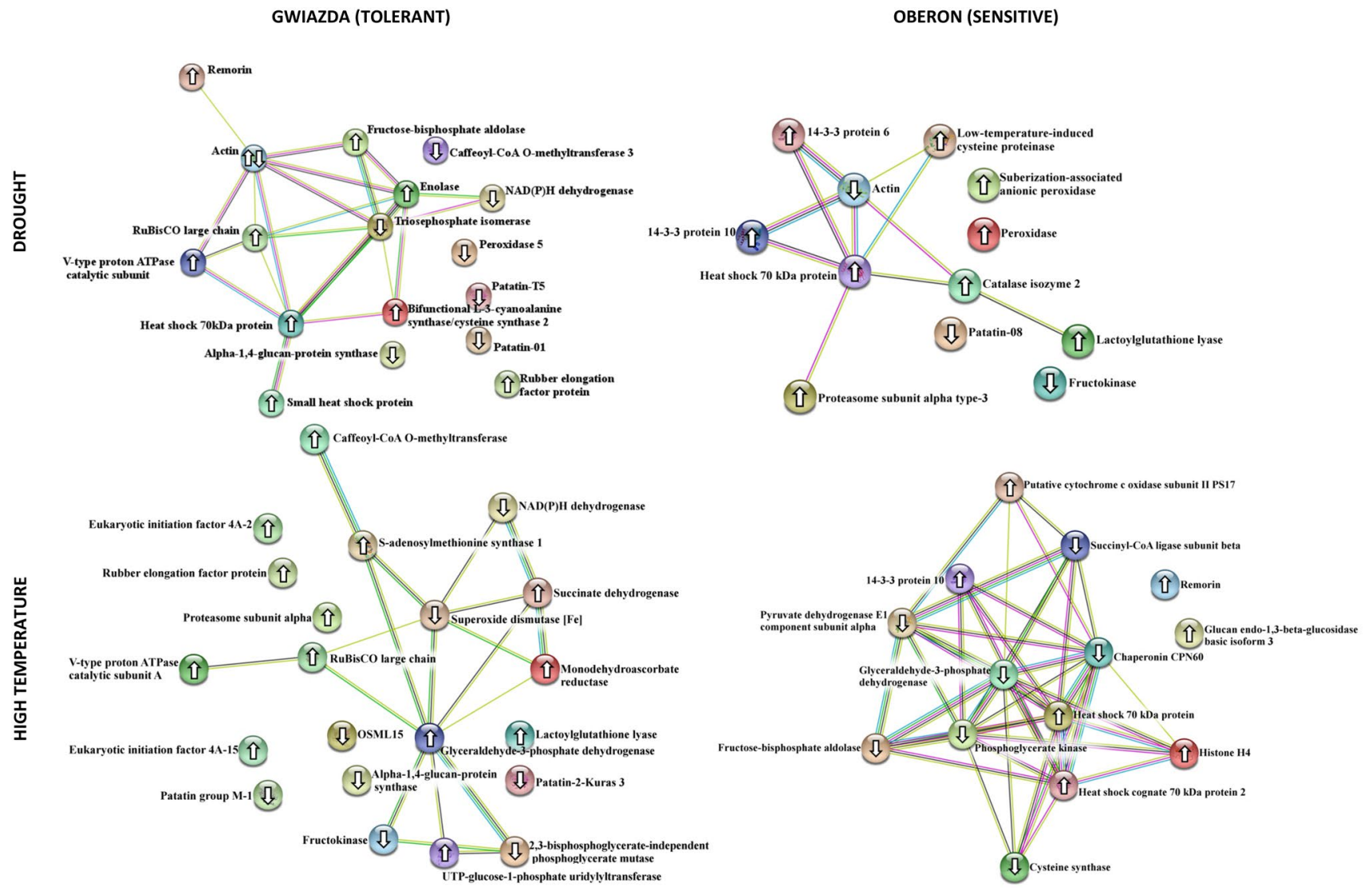

Fig. 7 Proteins relationship networks of two potato cultivars differing in drought and high temperature tolerance subjected to drought and high temperature stress by STRING software version 11.0 accessible online (https://string-db.org). Search performed for multiple proteins, with protein interaction level set at high $(0.700)$ 
has been observed in the tolerant cultivar subjected to high temperature. It was speculated that the induction of S-adenosylmethionine synthetase under salt conditions in rice roots allowed the plants to cope with the higher demand for S-adenosylmethionine involved in the methylation of lignin monomers prior to their polymerization (Guo et al. 2014). The process of lignification may be enhanced in response to high temperature due to the simultaneous increase of caffeoyl-CoA 3-O-methyltransferase, which was observed in roots of tolerant cultivar. These results indicate that $\mathrm{S}$-adenosylmethionine synthetase may be a key enzyme, responsible for potato tolerance to high temperature.

Enhanced levels of actin in leaves, hypocotyl, and roots of drought affected soybean seedlings point to the involvement of actin in the repair of membranes damaged by drought (Mohammadi et al. 2012). On the other hand, the expression of actin genes was reduced in drought-treated Hordeum vulgare leaves (Śniegowska-Świerk et al. 2015). Our research has shown that in response to drought, an increase in the abundance of one of the isoforms of actin (spot 5) but a decrease in the other (spot 16) in a tolerant cultivar was observed, whereas in the sensitive plant, only a decrease (spot 35) was detected. The decreased abundance of the cytoskeleton proteins suggests that cell growth was suppressed in response to drought. It may be due to the different functions of actin isoforms. In response to stress, the density of actin filaments increase, therefore, the increased abundance of actin isoform involved in creation of thick filaments is important (Kijima et al. 2018).

The decrease in alpha-1,4-glucan-protein synthase [UDPforming] (EC 2.4.1.112) relative content was observed in response to both stressors in the tolerant cultivar (spot 4 and 54), as well as in response to drought in the sensitive cultivar (spot 37 ). The changes in this protein abundance were observed in various plants exposed to abiotic stress. For example, an increased abundance of enzyme was detected in the response of wheat to salinity (Grębosz et al. 2014), however, decreased abundance of this enzyme has been observed in the poplar response to drought (Plomion et al. 2006). Alpha-1,4-glucan-protein synthase is involved in synthesis of $\alpha$-glucan, which is an essential component of starch, primary reserve material of plants (Kok-Jacon et al. 2003). Therefore, biosynthesis of starch is probably impaired in potato roots in the absence of available water as it was previously observed in drought-treated wheat (Ge et al. 2012). Moreover, this enzyme is also involved in the synthesis of hemicellulosic polysaccharides, especially xyloglucan, the main polysaccharide in type I cell walls. A positive correlation between alpha-1,4-glucan-protein synthase transcript levels and the active synthesis of cell wall components was found in potato (Wald et al. 2003; Mélida et al. 2011). It indicates that potato response is characterized by inhibition of cell wall synthesis and cell growth, as well as a decrease in starch accumulation.

\section{Proteins involved in carbohydrate metabolism and energy production are abundant in the tolerant cultivar}

In roots of potato cultivars, nearly $33-40 \%$ of total drought- and heat-responsive proteins were involved in carbohydrate and energy metabolism e.g., glycolysis, tricarboxylic acid (TCA) cycle, electron transport chain, and ATP synthesis. In the sensitive cultivar, only $8 \%$ of proteins were more abundant under drought and high temperature, while in the tolerant cultivar, about $20 \%$ of proteins increased in abundance upon the influence of both stressors.

A significant decrease in the abundance of glycolytic enzymes, fructose-bisphosphate aldolase (EC 4.1.2.13; spot 80), glyceraldehyde-3-phosphate dehydrogenase (EC 1.2.1.12; spot 82), phosphoglycerate kinase (EC 2.7.2.3; spot 79) as well as pyruvate dehydrogenase (EC 1.2.4.1, spot 93) in the sensitive cultivar under high temperature, has been observed. In the tolerant cultivar under high temperature some of the glycolytic enzymes decreased in abundance e.g. 2,3-bisphosphoglycerate-independent phosphoglycerate mutase (EC 5.4.2.12, spot 47) and fructokinase (EC 2.7.1.4; spot 52), however abundance of glyceraldehyde-3-phosphate dehydrogenase (EC 1.2.1.12; spot 70) increased. Drought induced the increase in abundance of some of the glycolytic enzymes in tolerant cultivar e.g. enolase (EC 4.2.1.11; spot 7), and fructose-bisphosphate aldolase (EC 4.1.2.13; spot 21).

A decrease in abundance of fructose-bisphosphate aldolase upon stress was observed in various species, however, it was also found to be drought-increased in such plants as Oryza sativa (Pandey et al. 2010), Sporobolus stapfianus (Oliver et al. 2011), and Musa paradisiaca (Vanhove et al. 2012). Moreover, abundance of fructose-bisphosphate aldolase decreased in drought-sensitive cultivars of Malus domestica (Zhou et al. 2015), and Poa pratensis (Xu and Huang 2010), but increased in tolerant ones. Similar dependency has been observed in the tolerant cultivar under drought and in the sensitive cultivar under high temperature. The inhibition of fructose-bisphosphate aldolase could be a part of the mechanism enabling an accumulation of sugars, which could act as osmolytes or as an energy source for recovery.

Regarding enzymes of tricarboxylic acid cycle, an increase in abundance of succinate dehydrogenase (EC 1.3.5.1), which catalyzes succinate oxidation in the citric acid cycle and transfers the electrons to quinones, has been observed in the tolerant cultivar upon high temperature (spot 65). Moreover, two protein spots related to ATP production, identified as V-type proton ATPase catalytic subunit (EC 
3.6.3.14, spots 18 and 61), were found to be increased in abundance under drought and high temperature in tolerant cultivar. It suggests that some of the tolerant plants may have the ability to enhance energy production to maintain physiological activity and inhibit stress damage.

In the sensitive cultivar (Oberon), a decrease in the abundance of proteins associated with glycolysis has been observed. It could be linked to reduced accumulation of root biomass and regarded as a mechanism of sugar storage and accumulation, enabling rapid growth during recovery phase. A similar decrease of glycolysis-related enzymes in roots under drought stress was reported in soybean (Alam et al. 2010). However, in roots of some other species, such as the xerophyte wild watermelon, an up-regulation of glycolysis and tricarboxylic acid cycle was found (Yoshimura et al. 2008). The increased abundance of proteins related to glycolysis and the respiratory chain in the tolerant (Gwiazda) cultivar may also reflect an increased energy demand and/or enhanced mobilization of metabolites at phase of creation of the root architecture, as well as cellular activities in the root tissues. Tricarboxylic acid cycle is embedded into a larger metabolic network, constantly sharing substrates and products with other pathways (Sweetlove et al. 2010). The TCA cycle may be fueled by products derived from proteins and degradation of other macromolecules to produce sufficient ATP amount to meet the energetic needs of the plant under stress. The up-regulation of ATP-synthesis related enzymes could be explained by the need for energy, which is crucial for stress protection and maintaining tissue in a functional state under water limiting conditions.

\section{Changes in the abundance of protective proteins}

Changes in protein abundance concerned the plant defence system, especially the detoxification of reactive oxygen species. In the sensitive cultivar subjected to drought, they reached up to $76 \%$ of DAPs for the root.

Abundance of such repair proteins as 14-3-3 protein (spots 44, 90), proteasome subunit alpha (EC3.4.25.11; spots 46 and 56), heat shock $70 \mathrm{kDa}$ protein (spots 20, 33, 84 and 87 ) increased in potato roots upon soil drought and high temperature. In similar proteomic experiments, some members of the 14-3-3 protein family were found to be increased under drought-treatment in plant species, such as rice (Yashvardhini et al. 2018) or Arabidopsis thaliana (Sun et al. 2014). Our research has shown that in the sensitive cultivar, there is an increase in the abundance of these proteins under drought and high temperature treatment. One can suppose that increased abundance of the 14-3-3 proteins contributes to the initiation of stress responses and other signal transduction pathways (Kelle and Radwan 2015).

Another protective protein that increased in abundance were $\alpha$ subunits of proteasome in the sensitive cultivar under drought (spot 46) and the tolerant cultivar under high temperature (spot 56). Literature data indicates that the $\beta$-type subunits are mainly involved in proteolytic activities, whereas the $\alpha$-type subunits are probably involved in maintaining the structure of the proteasome molecule (Zwickl et al. 1992). As a result, denatured and abnormal proteins can undergo proteolysis and released amino acids can be recycled by the plant in the processes of synthesis of proteins that are crucial in the current metabolic state (Zagdańska $2001)$. It was proven that in tobacco plants subunit, $\beta 1$ and two $\alpha$ subunits ( $\alpha 3$ and $\alpha 6$ ) were included in newly reassembled proteasomes called "plant defence proteasomes"(Suty et al. 2003; Lequeu et al. 2005).

Our research has also shown an increase in the abundance of heat shock $70 \mathrm{kDa}$ protein under drought in both the sensitive (spot 33) and the tolerant (spot 20) cultivar. Heat shock protein 70 (Hsp70) and small heat shock proteins (sHsp) have a wide range of cellular functions, including not only acting as "molecular chaperones", but also reducing the intracellular level of reactive ROS. The increased abundance of small heat shock protein (spot 13) has been observed in a tolerant cultivar in response to drought. The high abundance of members of the Hsps family in the sensitive and the tolerant cultivar upon their exposure to drought and high temperature may suggest that they belong to a common defensive mechanism.

In response to drought and high temperatures, an increased abundance of antioxidant proteins, including GPOX (spot 30), monodehydroascorbate reductase (EC 1.6.5.4; spot 63) and CAT (spot 34) was observed in sensitive and resistant cultivars. The increased activity of antioxidant enzymes in response to drought resulted from the increased concentration of ROS that may cause a chemical damage to DNA, lipids, and proteins (Ford et al. 2011). Thus, plant stress tolerance may be improved by the activation of antioxidant defense system. Enzymatic scavengers such as superoxide dismutase, catalase, ascorbate peroxidase and other peroxidases, mono- and dehydroascorbate reductases and glutathione reductase can decrease ROS level, and thus maintain cell redox homeostasis (Boguszewska et al. 2010).

\section{Conclusion}

A comparison of the physiological responses of two potato cultivars differing in drought tolerance with the changes in the root proteome revealed that the main difference in the response of both cultivars to soil drought and high temperatures is associated with changes in the processes of energy production and conservation. Our findings clearly indicate that active plant responses to soil drought and high temperatures require metabolic energy. The non-photosynthesizing 
roots of the sensitive cultivar mainly used previously generated energy reserves to activate enzymes associated with defense mechanisms and removal of ROS. In addition, enzymes associated with glycolysis and energy production were inhibited under drought or high temperatures. Therefore, it is possible that after consuming the energy reserves to combat the prolonged oxidative stress, the plants are not able to engage other survival mechanisms, which means the breakdown of stress tolerance. Excessive use of energy reserves results in a decreased tuber yield and lower usefulness of the cultivar Oberon in cultivation.

In a tolerant cultivar, a different response is observed regardless of stress applied. In the cultivar Gwiazda, fine tuning of energy metabolism and defense system has been observed. Maintaining energy acquisition with simultaneous selective activation of the oxidative stress control system allows the plant to survive for a longer time. Moreover, maintaining energy reserves leads to lower reduction of potato tuber yield and thus make cultivar Gwiazda more useful for cultivation under high temperature and water deficiency conditions.

Acknowledgements We would like to thank professor Zagdańska for the invaluable help in writing this work. This study was supported by grants awarded by the Ministry of Agriculture, Poland (MRiRW: 59:4-3-00-3-02).

Open Access This article is licensed under a Creative Commons Attribution 4.0 International License, which permits use, sharing, adaptation, distribution and reproduction in any medium or format, as long as you give appropriate credit to the original author(s) and the source, provide a link to the Creative Commons licence, and indicate if changes were made. The images or other third party material in this article are included in the article's Creative Commons licence, unless indicated otherwise in a credit line to the material. If material is not included in the article's Creative Commons licence and your intended use is not permitted by statutory regulation or exceeds the permitted use, you will need to obtain permission directly from the copyright holder. To view a copy of this licence, visit http://creativecommons.org/licenses/by/4.0/.

\section{References}

Ahmad R, Kim YH, Kim MD, Kwon SY, Cho K, Lee HS, Kwak SS (2010) Simultaneous expression of choline oxidase, superoxide dismutase and ascorbate peroxidase in potato plant chloroplast provides synergistically enhanced protection against various abiotc stresses. Physiol Plant 138:520-533

Ahn YJ, Claussen K, Zimmerman JL (2004) Genotypic differences in the heat-shock response and thermotolerance in four potato cultivars. Plant Sci 166:901-911

Aksoy E, Demirel U, Ozturk ZN, Caliskan S, Caliskan ME (2015) Recent advances in potato genomics, transcriptomics, and transgenics under drought and heat stress: a review. Turkish J Bot 39:920-940

Alam I, Lee DG, Kim KH, Park CH, Sharmin SA, Lee H, Oh KW, Yun BW, Lee BH (2010) Proteome analysis of soybean roots under water logging stress at an early vegetative stage. J Biosci 35(1):49-62

Beers RF, Sizer IW (1952) A Spectrophotometric method for measuring the breakdown of hydrogen peroxide by catalase. J Biol Chem 195:133-140

Binod PL, Bhim BK, Duryodhan C, Bishnu PP, Sung JS, On-Sook H, Yul RK (2015) Growth and yield characters of potato genotypes grown in drought and irrigated conditions of Nepal. Int J Appl Sci Biotechnol 3:513-519

Black CA (1965) Methods of soil analysis in Part I physical and mineralogical properties. American Society of Agronomy, Madison

Boguszewska D, Grudkowska M, Zagdańska B (2010) Droughtresponsive antioxidant enzymes in potato (Solanum tuberosum L. ). Potato Research 53:373-382

Boguszewska-Mańkowska D, Pieczyński M, Wyrzykowska A, Kalaji HM, Sieczko L, Szweykowska-Kulińska Z, Zagdańska B (2018) Divergent strategies displayed by potato (Solanum tuberosum L.) cultivars to cope with soil drought. J Agron Crop Sci 204:13-30

Boguszewska-Mańkowska D, Zarzyńska K, Nosalewicz A (2020) Drought differentially affects root system size and architecture of potato cultivars with differing drought tolerance. AJPR 97(1):54-62

Bradford MM (1976) A dye binding assay for protein. Anal Biochem $72: 248-254$

Bray EA (2004) Genes commonly regulated by water-deficit stress in Arabidopsis thaliana. J Exp Bot 55(407):2331-2341

Chance B, Maehly AC (1955) Assay of catalase and peroxidase. Method Enzymol 2:764-775

Chaves MM, Maroco JP, Pereira JS (2003) Understanding plant response to drought-from genes to the whole plant. Funct Plant Biol 30:239-264

Cornic G, Massaci A (1996) Leaf photosynthesis under drought stress. In Photosynthesis and the environment, Springer, New York

Dahal K, Li XQ, Tai H, Creelman A, Bizimungu B (2019) Improving potato stress tolerance and tuber yield under a climate change scenario-a current overview. Front Plant Sci 10:563

Deguchi T, Naya T, Wangchuk P, Itoh E, Matsumoto M, Zheng X, Gopal J, Iwama K (2010) Aboveground characteristics, yield potential and drought tolerance in "Konyu" potato cultivars with large root mass. Potato Res 53:331-340

FAOSTAT (2016) Food and Agriculture Organization of the United Nations (FAO). FAOSTAT Database

Ford KL, Cassin A, Bacic A (2011) Quantitative proteomic analysis of wheat cultivars with differing drought stress tolerance. Front Plant Sci 2:44

GAIN (2010) Global agricultural information network of the USDA Foreign Agricultural Service, GAIN Report No RS1060.

Ge P, Ma C, Wang S, Gao L, Li X, Guo G, Ma W, Yan Y (2012) Comparative proteomic analysis of grain development in two spring wheat varieties under drought stress. Anal Bioanal Chem 402:1297-1313

Gietler M, Nykiel M, Orzechowski S, Fettke J, Zagdańska B (2017) Protein carbonylation linked to the wheat seedlings tolerance to the water deficiency. Environ Exp Bot 137:84-95

Grębosz J, Badowiec A, Weidner S (2014) Changes in the root proteome of Triticosecale grains germinating under osmotic stress. Acta Physiol Plant 36:825-835

Guo M, Wang R, Wang J, Hua K, Wang Y, Liu X, Yao S (2014) ALT1, a Snf2 family chromatin remodeling ATPase, negatively regulates alkaline tolerance through enhanced defense against oxidative stress in rice. PLoS ONE 9:e112515

Heath RL, Packer L (1968) Photoperoxidation in isolated chloroplasts. I. Kinetics and stoichiometry of fatty acid peroxidation. Arch Biochem Biophys 125:189-198

Hijmans RJ (2003) The effect of climate change on global potato production. Am J Potato Res 80:271-280 
Iwama K (2008) Physiology of the potato: New insights into root system and repercussions for crop management. Potato Res 51:333-353

Joshi M, Fogelman E, Belausov E, Ginzberq I (2016) Potato root system development and factors that determine its architecture. J Plant Physiol 205:113-123

Kaur G, Sharma S, Das N (2020) Comparison of catalase activity in different organs of the potato (Solanum tuberosum L.) cultivars grown under field condition and purification by three-phase partitioning. Acta Physiol Plant 42:10

Kelle CK, Radwan O (2015) The functional role of 14-3-3 proteins in plant-stress interactions. i-ACES 1(2):100-110

Kijima ST, Staiger CJ, Katoh K, Nagasaki A, Ito K, Uyeda TQP (2018) Arabidopsis vegetative actin isoforms, AtACT2 and AtACT7, generate distinct filament arrays in living plant cells. Sci Rep $8(1): 4381$

Kok-Jacon GA, Ji QIN, Vinckena JP, Vissera RGF (2003) Towards a more versatile $\alpha$-glucan biosynthesis in plants. J Plant Physiol 160(7):765-777

Kostyuk V, Potapovitch A (1989) Superoxide-driven oxidation of quercetin and a simple sensitive assay for determination of superoxide dismutase. Biochem Int 19:1117-1124

Lequeu J, Simon-Plas F, Fromentin J, Etienne P, Petitot AS, Blein JP, Suty L (2005) Proteasome comprising a beta1 inducible subunit acts as a negative regulator of NADPH oxidase during elicitation of plant defense reactions. FEBS Lett 579:4879-4886

Levy D, Veilleux RE (2007) Adaptation of potato to high temperatures and salinity - a review. Am J Potato Res 84:487-506

Li W, Nguyen KH, Chu HD, Ha CV, Watanabe Y, Osakabe Y et al (2017) The karrikin receptor KAI2 promotes drought resistance in Arabidopsis thaliana. PLoS Genet 13(11):e1007076

Mélida H, Caparrós-Ruiz D, Álvarez J, Acebes JL, Encina A (2011) Deepening into the proteome of maize cells habituated to the cellulose biosynthesis inhibitor dichlobenil. Plant Signal Behav 6(1):143-146

Minhas JS, Singh B, Kumar D, Joseph TA, Prasad KSK (2001) Selection of heat tolerant potato genotypes and their performance under heat stress. J Indian Potato Assoc 28:132-134

Mittler R (2002) Oxidative stress, antioxidants and stress tolerance. Trends Plant Sci 7:405-410

Mittler R (2006) Abiotic stress, the field environment and stress combination. Trends Plant Sci 11(1):15-19

Mohammadi PP, Moieni A, Hiraga S, Komatsu S (2012) Organ-specific proteomic analysis of drought-stressed soybean seedlings. J Proteomics 75(6):1906-1923

Monneveux P, Ramierez DA, Pino M-T (2013) Drought tolerance in potato $(S$. tuberrosum L.). Can we learn from drought tolerance research in cereals? Plant Sci 205-206:76-86

Obidiegwu JE (2015) Coping with drought: stress and adaptive responses in potato and perspectives for improvement. Front Plant Sci 6:1-23

Oliver MJ, Jain R, Balbuena TS, Agrawal G, Gasulla F, Thelen JJ (2011) Proteome analysis of leaves of the desiccation-tolerant grass, Sporobolus stapfianus, in response to dehydration. Phytochemistry 72:1273-1284

Pandey A, Rajamani U, Verma J, Subba P, Chakraborty N, Datta A, Chakraborty S, Chakraborty N (2010) Identification of extracellular matrix proteins of rice (Oryza sativa L.) involved in dehydration-responsive network: a proteomic approach. J Proteome Res 9:3443-3464

Perez-Riverol Y, Csordas A, Bai J, Bernal-Llinares M, Hewapathirana S, Kundu DJ, Inuganti A, Griss J, Mayer G, Eisenacher M, Pérez E, Uszkoreit J, Pfeuffer J, Sachsenberg T, Yilmaz S, Tiwary S, Cox J, Audain E, Walzer M, Jarnuczak AF, Ternent T, Brazma A, Vizcaíno JA (2019) The PRIDE database and related tools and resources in 2019: improving support for quantification data. Nucleic Acids Res 47(D1):D442-D450

Pieczyński M, Wyrzykowska A, Milanowska K, BoguszewskaMańkowska D, Zagdańska B, Karlowski W, Jarmolowski A, Szweykowska-Kulińska Z (2018) Genome-wide identification of genes involved in the potato response to drought indicates functional evolutionary conservation with Arabidopsis plants. Plant Biotechnol J 16(2):603-614

Piro G, Leucci MR, Waldron K, Dalessandro G (2003) Exposure to water stress causes changes in the biosynthesis of cell wall polysaccharides in roots of wheat cultivars varying in drought tolerance. Plant Sci 165:559-569

Plomion C, Lalanne C, Claverol S, Meddour H, Kohler A, BogeatTriboulot MB, Barre A, Le Provost G, Dumazet H, Jacob D, Bastien C, Dreyer E, de Daruvar A, Guehl JM, Schmitter JM, Martin F, Bonneu M (2006) Mapping the proteome of poplar and application to the discovery of drought-stress responsive proteins. Proteomics 6:6509-6527

Rykaczewska K (2013) The impact of high temperature during growing season on potato cultivars with different response to environmental stresses. Am J Sci 04:2386-2393

Sattelmacher B, Marschner H, Kuhne R (1990) Effects of the temperature of the rooting zone on the growth and development of roots of potato (Solanum tuberosum). Ann Bot 65:27-36

Śniegowska-Świerk, K., Dubas, E., Rapacz, M., 2015. Droughtinduced changes in the actin cytoskeleton of barley (Hordeum vulgare L.) leaves. Acta Physiol Plant 37, 73.

Spector T (1978) Refinement of the Coomassie blue method of protein quantitation. A simple and linear spectrophotometric assay for less than or equal to 0.5 to 50 micrograms of protein. Anal Biochem 86:142-146

Strasser RJ, Tsimilli-Michael M, Srivastava A (2004) Analysis of the chlorophyll a fluorescence transient. Chlorophyll a fluorescence: a signature of photosynthesi. Advances in photosynthesis and respiration series. Academic Publishers, Rotterdam, pp 321-362

Sun X, Luo X, Sun M, Chen C, Ding X, Wang X, Yang S, Yu Q, Jia B, Ji W, Cai H, Zhu Y (2014) A Glycine soja 14-3-3 protein GsGF14o participates in stomatal and root hair development and drought tolerance in Arabidopsis thaliana. Plant Cell Physiol 55(1):99-118

Suty L, Lequeu J, Lançon A, Etienne P, Petitot A-S, Blein J-P (2003) Preferential induction of $20 \mathrm{~S}$ proteasome subunits during elicitation of plant defense reactions: towards the characterization of plant defense proteasomes. Int J Biochem Cell Biol 35:637-650

Sweetlove LJ, Beard KFM, Nunes-Nesi A, Fernie AR, Ratcliffe RG (2010) Not just a circle: flux modes in the plant TCA cycle. Trends Plant Sci 15(8):462-470

Szklarczyk D, Franceschini A, Kuhn M, Simonovic M, Roth A, Minguez P, Doerks T, Stark M, Muller J, Bork P et al (2011) The STRING database in 2011: functional interaction networks of proteins, globally integrated and scored. Nucleic Acids Res 39:D561-D568

Tu Y, Rochfort S, Liu Z, Ran Y, Griffith M, Badenhorst P, Louie G, Bowman M, Smith K, Noel J, Mouradov A, Spangenberg G (2010) Functional analysis of Caffeic acid O-methyltransferase and cinnamoyl-CoA-reductase genes from perennial reygrass (Lolium perenne). Plant Cell 22:3357-3373

Vanhove AC, Vermaelen W, Panis B, Swennen R, Carpentier SC (2012) Screening the banana biodiversity for drought tolerance: can an in vitro growth model and proteomics be used as a tool to discover tolerant varieties and understand homeostasis. Front Plant Sci 3:176

Wald FA, Kissen R, Jardin P, Moreno S (2003) Characterization of UDP-glucose: protein transglucosylase genes from potato. Plant Mol Biol 52(4):705-714 
Wang W, Vignani R, Scali M, Cresti M (2006) A universal and rapid protocol for protein extraction from recalcitrant plant tissues for proteomic analysis. Electrophoresis 27:2782-2786

Watt M, Magee LJ, McCully ME (2008) Types, structure and potential for axial water flow in the deepest roots of field grown cereals. New Phytol 178:135-146

Xu C, Huang B (2010) Comparative analysis of drought responsive proteins in kentucky bluegrass cultivars contrasting in drought tolerance. CSSA 50:2543-2552

Yashvardhini N, Bhattacharya S, Chaudhuri S, Sengupta DN (2018) Molecular characterization of the 14-3-3 gene family in rice and its expression studies under abiotic stress. Planta 247(1):229-253

Yoshimura K, Masuda A, Kuwano M, Yokota A, Akashi K (2008) Programmed proteome response for drought avoidance/tolerance in the root of a $\mathrm{C} 3$ xerophyte (wild watermelon) under water deficits. Plant Cell Physiol 49:226-241

Zagdańska B (2001) Mechanizmy degradacji białek i ich znaczenie w odporności roślin na mróz i suszę. Biuletyn Instytutu Hodowli i Aklimatyzacji Roślin 218-219:15-28
Zarzyńska K, Boguszewska-Mańkowska D, Nosalewicz A (2017) Differences in size and architecture of the potato cultivars root system and their tolerance to drought stress. Plant Soil Environ 63:159-164

Zhou L, He Y, Ma Z, Liang R, Wu R, Wu Y (2015) One-step degradation of cellulose to 5-hydroxymethylfurfural in ionic liquid under mild conditions. Carbohyd Polym 117(6):694-700

Zwickl P, Grziwa A, Puehler G, Dahlmann B, Lottspeich F, Baumeister W (1992) Primary structure of the Thermoplasma proteasome and its implications for the structure, function, and evolution of the multicatalytic proteinase. Biochemistry 31(4):964-972

Publisher's Note Springer Nature remains neutral with regard to jurisdictional claims in published maps and institutional affiliations. 